\title{
HOLY ICON - THE REALITY OF KNOWLEDGE AND VISION OF GOD
}

\author{
Ph.D. Marin BUGIULESCU \\ Professor, Member of Dumitru Stăniloae Scientific and \\ Interdisciplinary Research Center, Valahia University, Târgoviște, \\ ROMANIA, \\ E-mail: m_bugiulescu@yahoo.com
}

\begin{abstract}
According to the Orthodox Theology, holy Icon is a reality of knowledge and vision of God. The icon is an embodiment of the love of God, thus the central theological ground of the veneration of icons is a Christological one. For the theology of the icon, the concept of the face as a reflection of the prototype is central. The specificity of the Orthodoxy shows us that Theology is the science of the complete knowledge with a direct existential implication of the only truth about life-Maker, iconically expressed by God - Holy Trinity. The theological background of knowledge is essentially of ecclesial nature, as a gracious ambience in which the Divine Revelation represents the power of Truth. That is why Church is the guarantee and the authenticity of the free and infallible knowledge of the divine truth which it internally possesses.
\end{abstract}

Keywords: Orthodox Theology; icon; Church; vision and knowledge of God;

\section{INTRODUCTION}

Knowledge of God, according to Orthodox thought, is possible, first of all, because of the Incarnation of Christ, but also the character of a personal being specific to both God and man. God's knowledge relates to divine iconology, to His "exits" outside His Being. Therefore, in terms of Christian theology, knowledge is harsh and not real, for man cannot know the Divine, Absolute and Eternal Being, but only its manifestation in time and space through the three Persons of the Holy Trinity and through all acts of divine revelation.

God's knowledge is a natural reality in the process of acquiring holiness or deification of man, and it represents his mission in the world, but also the sublime and mysterious aspect of Orthodox spirituality synthesized by Eastern patristic theology through living in grace and participation in the love of the Holy Trinity.

Man, from the first moment of creation by God, is called to acquire the state of resemblance to his Archetype. Deification is the holy, sanctifying condition that personalizes ontologically and indelible light and divine glory in the reality of eternal existence. If the beginning of this process of communion, love, and grace, between man and Creator is covered with reason in cognition expressed as a way of life, in the ontological sense, theosis is the state of apogee or the last stage of perfection by which man, ceaselessly, participate in the eternal love of the Holy Trinity.

In the theology of the Orthodox Church, the ontological and phenomenological aspects of the deification of man, as a living with Christ and as a life in the Holy Spirit, as high ascetic and mystical states are correlated with the view of the light of the world. In this 
sense both the state of gnosis and theosis are simultaneous realities of the presence of God, but as Paul Evdokimov points out:

"There are two aspects that structure the mystical union: the real presence of God in the deified soul and transcendence absolute of the same God Who remains eternally inaccessible and infinitely remote" 1 .

However, deification is a state of dynamic communion and is not conceived as a static identity in a substantial ontological conception. The ontological basis of deification is the Person and the Work of Christ, the Son of God Incarnate, in which the participation of all nature, and not the identity of the essence, including dynamic, reciprocal and personalistic elements in the relationship between the Creator and creation, is accomplished. The ontological restoration of the human flesh assumed by Christ as a body is personally acquired by incorporation into the Church, and therefore, in a broad sense, the process of deification begins with the Holy Sacrament of Baptism, but in a stark sense this is a purifying and transfigurative harvest event that opens the way to the knowledge of God and to the sight of the uncreated light, the glory of God, through the sharing of eternal love, pregnant in this world through union with Christ.

The process of God's knowledge is both cataphatic and apophatic, which implies

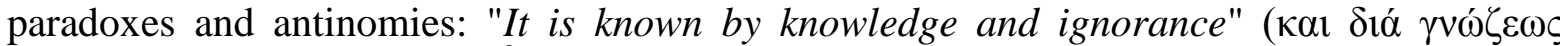

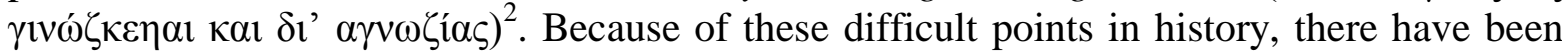
many Gnostic doctrines, both Christian and non-Christian, claiming to have the true knowledge that leads to knowledge.

Etymologically the word gnosis (Gr. gnosis) means knowledge. In the sense of presenting modernist sciences, Gnosticism is the result of syncretism, between Hellenistic and Oriental thinking. In the spirit of patristic thinking centered on divine revelation, the knowledge of God is existentialist personality, which involves meeting, personal communion and personality with peers and God. Unlike Gnosticism, where knowledge itself is the goal of Gnostics, in Christian theology knowledge is a means, a set of contents that go beyond the given sphere of knowledge. This ultimate goal is union with God or deification, the state of Orthodox iconography.

The icon, defined magisterially as "opened window in heaven", is a representation of the transcendental reality, spiritual in immanence, in the material world, felt as the presence of holiness and of the Holy Deity in the sacramental, ecclesial hierarchy. This holy presence works by God the Holy Trinity, which really gives man the possibility of communion, salvation, and sanctification.

\section{HOLY ICON, THE EMBODIMENT OF THE LOVE OF GOD - THE CHRISTOLOGICAL BASIS}

The icon is an embodiment of the love of God, therefore the central theological ground of the veneration of icons is the Christological one. For the theology of the icon, the concept of the face as a reflection of the prototype is central. Light and grace within the ecclesial is based on the Person and the Work of Christ the Son of God Incarnate in an inseparable relationship with the Holy Spirit and active through the members of the harvest Body that He sanctifies and become saints. The Holy Icons depict the state of holiness

${ }^{1}$ Paul Evdokimov, Ortodoxia, trad. de Rom. Irineu Popa, Bucureşti, 1996, p. 123, 172

${ }^{2}$ Sfântul Dionisie Areopagitul, Despre numele dumnezeieşti, 7, 3, PG 3, 872 a. 
through which are the harsh presence and spiritual realities of God's knowledge and vision. Thus "the icon in its being, and especially when it is a" feast icon:

\begin{abstract}
"with the representation of a central mystery of faith and Revelation, is not an image for private meditation. Its theological place is only the Liturgy, where it completes the preaching of the Word by preaching the image" ${ }^{3}$.
\end{abstract}

By entering the communion of saints with icons, the Christian shares the light of the saving grace that comes from the sacrifice of Christ, present in the ecclesial framework through the Holy Mysteries.

The theology of the icon referring to the Person of Christ as a synthesis of the patristic teaching was officially formulated at the Seventh Ecumenical Synod (Nicaea 787), by the cultural foundation expressed by the formula of St. John Damascene ${ }^{4}$, according to which honor passes from the face to the prototype. This definition asserts that the icon is a similitude, a pattern, a presence of someone who shows in it the imaginary one. The icon expresses the original, but is not the original itself; here we distinguish both similarities and differences. The icon encompasses and presents the original gracefully, but it is not one with it because then we would not need it, being the original itself. This teaching is also found in St. Basil the Great, which speaks of the unity of the Trinitarians, says:

"The King's face is called king, but we do not have two kings. Neither power breaks, nor glory divides. And as the authority that governs us is one, so also the glory given to us is one and not many, because the honor given to the image passes over the prototype" 5 .

St. John Damascene clarifies this problem by the notion of image - eikon which has various forms, but in a limited sense the icon means: 1) the presentation of the Table of the Law, the Old Testament, and especially 2) the painting of the faces of the virtuous and holy men $^{6}$. The veneration of the icon is called veneration ( $\left.\pi \rho 0 \sigma \kappa v v \eta \sigma \nu \varsigma \varsigma\right)$, but honor to God is supreme and is called adoration $(\lambda \alpha \tau \rho \varepsilon 1 \alpha)$. Veneration refers to the Mother of God and to the saints, and she is dependent on the worship of God. In icons, even though we are talking about the presence of God through the iconomachy of Christ and the Holy Spirit, honesty is relative because it expresses the devotion to the divine actions that revelation gives to man for the purpose of knowing and seeing God, because man is a physical being who needs concrete, physical forms, of course they do not express the Being of God, but His works. Thus: "If the Emperor's icon is the Emperor, then Christ's icon is also Christ"7. The theology of the person, by reference to Christ's Person and Work, has also made it possible to explain the honesty of the holy image represented, rather than the material from which the icon is made. By the icon God, "He that is unseen is seen" (John 1:17). This is the direct result of the Incarnation of Christ in the thought of Saint Theodore the Studite, and that is why the icon is the representation of truth, not a carved image or an idol, which meant a false divinity to which worship refers and ceases, Exit 20.4) ${ }^{8}$.

As the fullness of the revelation Jesus Christ, the true God and true Man, through His Person and Opera represents the love of the Holy Trinity that makes shine and uncreated light shine through the transfiguration of creation and the deification of man. The non-

${ }^{3}$ Gabriel Bef gf unge, Icoana Sfintei Treimi a Cuviosului Andrei Rubliov, traducere de Ioan I.Ică jr., Editura Deisis, Sibiu, 1996, p. 92

${ }^{4}$ Sfântul Ioan Damaschin, Cele trei tratate contra iconoclastilor, trad. D. Fecioru, Bucuresti, 1998, p.4

${ }^{5}$ Sfântul Vasile cel Mare, Despre Sfântul Duh, PSB 12, Editura IBM al BOR, Bucureşti 1988, p. 60

${ }^{6}$ Cristoph Schonborn, Icoana lui Hristos, Bucureşti, Ed. Anastasia, 1996, p.149

${ }^{7}$ Sfântul Ioan Damaschin, Cele trei tratate contra iconoclastilor, trad. D. Fecioru, Bucuresti, 1998, p. 69

${ }^{8}$ Sfântul Teodor Studitul, Antirrheticos I, P.G., XCIX, col. 330-333 
Patriotic thought of Father Dumitru Staniloae is, in fact, an iconological theological synthesis, anchored in the optimistic-realist conception specific to Orthodoxy, in which the transcendental, scholastic and abstract intellectualism of Western thought is not an argumentative force because the basis is the living revelation expressed by the experience mystical and mystical within the liturgical-community framework of the ecclesial space. Thus Father Stăniloae puts into dialogue the patristic thinking, argued with texts of particular accuracy with the ecclesial life, in the center of which lies the deified human, fully represented by Christ, the God-Man.

\begin{abstract}
„If the very existence of the icon relies on the Incarnation of the Second Person of the Holy Trinity, the Incarnation is, in turn, supported and proved by the image. In other words, the icon is a guarantor of the illusory reality of the Divine Incarnation. That is why, in the eyes of the Church, the denial of the icon of Christ equates to the denial of His Incarnation"9.
\end{abstract}

The same idea is supported by Michel Quenot as follows: "ignoring the icon means to incarnate the Incarnation, which it confesses and in which it finds its beginning"10. Starting from Christ and passing through the ecclesial and mystical space, Father Staniloae defines man and the world with finesse and delicacy, outlining the theology of the icon in a concentric spiral of iconic knowledge. In this sense, he says:

\footnotetext{
"The Byzantine icon is solidarity with the beginning patristic exegesis of Holy Scripture. The icon makes it plain in the image and simultaneously what exegese and patristic preaching sink to say in words and in succession" ${ }^{11}$.
}

So, the theological concept promoted by Father Dumitru Stăniloae is an eminently personalist icon, but revealed through Christ, the Son of God, who through the Incarnation has a person composed of divine nature and human nature. From this perspective, man is the one who has to conform to the rationality of his own nature and the world, to maintain his own will and freedom in the good will of the Creator (God) who draws and keeps him in love and communion, all of which are actually implications of the divine image in human nature in a sacramental manner. At the basis of spiritual life lies the Christological reality that the Church updates for its members Christians who live in the perspective of acquiring holiness displayed on the imagery by icons.

\title{
2. GOD'S KNOWLEDGE AND VISION WITHIN THE ECCLESIAL SACRAMENTAL HARVEST
}

Talking about God, rationalizing Divine Existence, thinking that there is a Supreme Being is in fact a call to what the Creator has put into human being, the mental and mental aspect through which man reaches the act of knowledge, understanding, and science. This complex and antinomic process is a revelation and certainty that, at least from a logical point of view, is possible. Man ascends with the mind to perceive the mysteries of God and creation, and this presupposes, on the one hand, the understanding of one's own existence and the existence of God on the other. From the theological thinking perspective, this act is not based on the intellectual processes specific to man scientifically advanced with the passage of time, because God is not an idea, a man-made conception, but is grounded in God's revelation, the Divine Revelation. God exists and is revealed to men, of course

\footnotetext{
${ }^{9}$ Leonid Uspensky, Teologia icoanei, traducere de Teodor Baconsky, Ed. Anastasia, Bucureşti, 1994, p. 80

${ }^{10}$ Michel Quenot, Icoana, fereastră spre absolut, Editura Enciclopedică, 1993, p. 15

${ }^{11}$ Pr. Dumitru Stăniloae, Introducere, la Wilhelm Nyssen, Inceputurile picturii bizantine, traducere de Pr. D. Stăniloae, Edit. IBM al BOR, București, p. 8.
} 
progressively in the Old Testament and fully through Jesus Christ. Man's reception of this revelation not only involves intellectual mechanisms, neither scientific schemes nor philosophical views, but a relationship, a bond of love and communion of man with God, specific to the personal beings, occasioned generally by the sacred and sacred space of the Church. Divine revelation is comprehended and transmitted by Sacred Scripture and Holy Tradition, but in close connection with the Church and Christ, which has authority over its formation, fixation, defense and explanation under the direct presence, assistance and inspiration of the Holy Spirit, of God.

Supernatural revelation is the source of faith, but also the record of God's works. It imposes the direct or indirect presence of God through dialogue and communion towards the full union with Him that is reached by faith (Hebrews 11:3). Divine supernatural revelation is contained in Holy Scripture and Holy Tradition, its ways of transmitting to us. Sacred Scripture and Holy Tradition are two ways or modes of storing, preserving, and transmitting Revelation. Holy Tradition is the permanence of the Church's dialogue with Christ.

Between Sacred Scripture and Holy Tradition there is no difference in the revealed substance or content, but only in the form and manner in which it was transmitted. Starting from the divine revelation data transmitted by Holy Scripture and Holy Tradition, the process of knowledge also involves conceptual coordination with logical, analogical and symbolic valences, using words, reasoning, images, symbols, analogies, according to the human way of thinking and understanding to express and define their realities and existence.

God's knowledge is a way of life that Jesus Christ the Son of God incarnate has made and which the Church makes possible to its members in the theandrical, sacramental environment. Man cannot know God without the dates of Divine Revelation, and especially without harvest and ecclesial life, through which he unites with Christ through the Holy Mysteries. The process of knowledge is continuous because what is to be known (God) is Absolute that is why the dogmatic theological knowledge is accomplished in eternity and involves a transformation of man, a sanctification of it, and a fulfillment of the divine image through the likeness of God.

The patristic teaching shows that by means of natural revelation in the analytical, deductive way through thinking man postulates the existence of the Creator-God. But more than that, the natural revelation presupposes the deciphering of the rationality of creation and the attainment of the One-Christ Reason, the Divine Logos. In the New Testament, the Savior is designated both as the "divine Logos" (John 1:1) and as the icon of the unseen God (Colossians 1: 15). "In Him, human reason has, as in his own Person, the knowledge of the infinity of divinity, and can communicate to men in an accessible way without end" ${ }^{12}$. This makes possible the presence of Christ as the Creator Logos, through which the world is the work of God Who takes care of it. Through Christ, the world becomes transparent, transparent for the glory of God. "His invisible things are seen from the creation of the world, being understood by the beings ..." (Rom. 1: 20-23). Saint Maximus the Confessor understands through the unseen the reasons of things, drawn up before centuries, which Saint Dionysius the Areopagite called good sayings.

"It is the rationale of things, drawn up before the ages of God, as he himself knew the
reasons that the holy men have the habit of calling themselves good things. These, being
invisible, are seen through the understanding of the beings. For all the creatures of God,
contemplated by us by nature, with the help of proper knowledge and knowledge, reveal to
us in secret the reasons that have been made and reveal through them the purpose set by God

${ }^{12}$ Pr. Dumitru Stăniloae, Chipul nemuritor al lui Dumnezeu, vol. I., Edit. Cristal, Bucureşti 1995, pp. 16-17. 
in all flesh, in this meaning and " The heavens say the glory of God, and the power of His hands proclaims her strength. " And eternal power and deification is Providence that keeps things together and the work of deification of those sustained by Providence" 13 .

In patristic theology, which Professor Dumitru Stăniloae has synthesized masterfully in his works, the importance of natural revelation is related to the knowledge of the creatures to raise to God's knowledge as a creative and supportive cause of all. This knowledge does not only remain at the level of understanding the creatures as opaque and separate things, without their foundation in the common and transparent fund of divine transcendence, but also involves a state of enlightenment. This knowledge of divine purposes in the world, called contemplation, is considered in Eastern spirituality, the second step following purification of passions, in the spiritual ascension of the long process of perfection.

Supernatural revelation deepens and illuminates natural revelation, so as to eliminate the danger of God's confusion with creation. On the basis of the character of personal Being, God reveals himself as a fused love kenotic in the saving action of the Incarnate Son, a reality explained by the theology of Redemption. Christian life in ecclesial space is both sacramental and ascetic, mystical. On the steps of spiritual ascension the man, beginning with the iconic sight of God, reaches the gracious knowledge of divine glory. Father Dumitru Stăniloae presents the apophatic theology, through the consciousness of the intellect's inability to express the divine being; this is the mystical theology of God's direct feeling and experience, which cannot be fully exposed in positive terms, that is why their denial is needed. For example, God is identified by Truth, Good, etc., but in reality He is more than these concepts. This thinking also applies to the theological definition and the theological expression of sacred icons that present divine glory.

\begin{abstract}
"Palamas speaking of divine light has understood it as a manifestation of God's personal or tripersonal. If we make a distinction between this light and the divine essence, we only understand that God's personal or tripersonal does not exhaust in every manifestation of Himself as a work or as uncreated grace or as light, the entire infinite substance of essence that exists and is held in movement, or in endless works, by hypostasis, or by the Trinity of hypostases. But speaking of the work or the grace, or the divine light, Palamas always understands the Person or the Divine Persons as a Subject, or as the Subjects of the Work, or Grace, or Light." 14
\end{abstract}

In this sense, Saint Irinaeus of Lugdunum states that:

\begin{abstract}
"The sight of God is always a revelation made by the will of God. The face of God that no one can see without dying becomes in the eschatological times the source of life for people will see God to live, becoming immortal through vision and progressing now on the path to God. God appeared to Moses on Mount Sinai as a presence, as a friend. In fact, the One who appeared to Him was the Word, but Moses could not see Him and asked Him to see more clearly the one He spoke with"15.
\end{abstract}

St. Athanasius states that "Adam's sight if he had managed to preserving divine resemblance by contemplation of God, he would have destroyed any possibility of altering

\footnotetext{
${ }^{13}$ Sfântul Maxim Mărturisitorul, Răspunsuri către Talasie, Filocalia 3, Traducere, introducere şi notede Pr. Prof. Dumitru Stăniloae, edit. Apologeticum, Bucureşti 2005, p.69

${ }^{14}$ Prof. Pr. Dumitru Stăniloae, Semnificaţia luminii dumnezeieşti în spiritualitatea şi cultul Bisericii Ortodoxe, în rev. Ortodoxia, nr. 3-4. an 1976, p.435

${ }^{15}$ Vladimir Lossky, Vederea lui Dumnezeu, Editura Deisis, Bucureşti 1995, p.34
} 
his wicked nature and would have become incomprehensible forever" ${ }^{16}$. Saint Basil the Great says:

"Through Christ is the ascension of the emotions, the deification of the weak, and the fulfillment that is in progress. He is the one who, shining sharply in those who are cleansed of all uncleanness, and turning into spiritual persons through communion with Himself. We can contemplate God in the Holy Spirit. Like the sun when a clear eye shines, the Holy Spirit will show you the image of the Unseen. In the delightful contemplation of this image you will see the ineffable beauty of the Archetype. In the Holy Spirit we see the image of the Son and through him we see the Archetype, the Father. God's whole view will be Trinitarian, a view of the Holy Spirit, through the Son, directed toward the Father" ${ }^{17}$.

St. Gregory of Nazianzus (328-390) claims that:

"Seeing God is contemplation of the Trinity, fully participating in His light. Those who will unite with the whole Spirit will be the heirs of the Perfect Light and the contemplation of the Holy Trinity. This is the heavenly kingdom." 18

On the rational path, man starts from effect to cause. It's knowledge of the world. The contemplation of the good and beautiful realities in the world leads to the acceptance of the existence of a Creator who, by analogy, receives some definitions similar to those of the created world. This is theologically expressed by the concept of cataphatic knowledge. By cataphatic knowledge, we are actually formulating the attributes of God; his loving exits in the face of man as an expression of uncreated divine energies. The attributes of God in Orthodox theology are identified by divine works or energies. Father Staniloae states in this sense that:

"We do not know the attributes of God except in their dynamism, and to the extent that we share them. But this does not mean that God Himself remains passive in His simplicity and the varied motion is projected upon us by Him" ${ }^{19}$.

Rational knowledge is not purely natural, because it is based on the supernatural revelation, but does not make use of all its content. So, the one who walks through the rational, cataphatic knowledge of God is led to the apophatic one, but this is expressed by the terms of the cataphasis. For this reason, the Holy Fathers often go into the talk of God from one to the other (cataphatism/ apophatism). The fact that God is beyond any affirmation and negation does not make His connection impossible with us. And that's why our great theologian says, "God is forever a mystery to man, but a mystery from which he irradiates more and more light, more love and life lived by man, more and more sense" ${ }^{20}$.

In ascetic and mystical theology, the sight of God's glory or light is superior to rational, affirmative and negative theology. It is superior to apophatic theology through spiritual living. This involves an over conceptual knowledge. But it is not forced by thought, but all those created and their ideas are covered by the true vision of divine light, above all. Through the view above the spiritual fathers understand the deifying work, so as an active view of it. That is why I know that the Divine Subject or the Person who produces this working view is working in it. This advance is lived as the harsh state of the Holy Spirit.

\footnotetext{
${ }^{16}$ Turcescu Lucian, Sfântul Grigore Palama teologia trinitară, în ,Studii Teologice”, nr. 4-6, 1995, p. 67

${ }^{17}$ Vladimir Lossky, Vederea lui Dumnezeu, ed.cit, p. 68

${ }^{18}$ Vladimir Lossky, Vederea lui Dumnezeu, ed.cit, p. 70

${ }^{19}$ Pr. Prof. Dumitru Stăniloae, Teologia Dogmatică Ortodoxă, vol I, Editura IBM al BOR, ediţia a II-a, Bucureşti, 1996, p. 105

${ }^{20}$ Pr. Prof. Dumitru Stăniloae, Chipul nemuritor al lui Dumnezeu, vol 1, ed. cit., p.180
} 
Apophatic is a direct relationship with the Person of the Holy Spirit in Christ, but also as the love of the heavenly Father.

Father Professor Dumitru Stăniloae shows that God has not created a world frozen in meaningless rationality, but a world destined to advance toward a goal: holiness. That is why knowledge is not regarded as an end in itself, but as a means, a set of teachings, instruments and methods, which must lead to the mystical union with God, to deification, and this process is both cataphatic, especially in apophatic. The knowledge of God, rationally inferred by the contemplation of creation, is required to be complemented by a superior apophatic knowledge. Patristic thought shows that the most visible sight in the Spirit is only those who come to the real and living union with God - the Holy Trinity expressed in the theandrical framework of the Church.

In a recent study dedicated to the theology of the icon, Father Professor Stefan Buchiu, while expressing his cultic and mystagogic character, says:

\begin{abstract}
"The cosmological and mystagogical value of the icon derives from the synthesis it creates between the created and uncreated plan. It is based on the theological principle of perichoresis, or the interpenetration of the natures in Christ. Godhead and humanity intertwine communicating their specific attributes to each other, as the cosmos seen with the unseen intersects through the icon, making them close and inward to each other. The reverse view of the icon renders those seen, weak to share the eternal ones of God, and shows that the meaning of the sharing is from the background of the icon to its destination, that is, this world. St. Maximus the Confessor that the world is an icon of God, indicating the meaning of communion between intelligible to sensitive, as we see in the Mistogogia that the navy as a constituent part of the Church shares the holiness of the altar. From this we see that the icon is completely unknown only from a mystagogical perspective. The saints are those looking outward, that is, their reality assimilates our perception of the flesh and places it in a view beyond the narrow limit of the physical eye. By detracting from the icon, the saints become partakers and present to the world we see as we live, being together fighters with those in the Fighting Church here. Hence the steady role of mediators between Christ and our people helping to achieve subjective salvation in each" ${ }^{21}$.
\end{abstract}

The Church, as the mysterious, sacramental body of Christ, through the Holy Spirit is holy and sanctified. The icon is a means of knowing God, understood as a theology of the revealed word, but expressed in pictures as a holy and sanctifying presence. That is why the icon is a preaching of the truths of Christian revelation within the ecclesial, and especially in the liturgical, doxological framework.

"The ecclesiological value and sacramental ritual of the icon refers to man's effort to maintain and grow in Christ, that is, to the likeness of the icon more and more to its Archetype. The church is a space for the genesis of the icon of both the seen and, above all, the invisible icon. It is the environment in which the icon draws an outline and the absence of which cannot even obtain identity"22.

The holy icons in the Church also highlight the archetypal state of man, holiness and saints acquired through the ascetic and mystical life understood as a likeness to God. Theologically man is an iconic being.

In this sense, man as a living icon of God is "created in His image" (Genesis 1: 26$27 ; 5,1,3 ; 9,6)$. "The face has the indestructible presence of grace inherent in human nature $^{\prime 23}$. The iconic manifestation of man is perfectly represented in the Incarnate Person of

\footnotetext{
${ }^{21}$ Pr. prof. Ştefan Buchiu, Valoarea teologică a icoanei, p. 4, a se vedea

http://patriarhia.ro/images/pdf/Patrimoniu/Valoarea_teologica_a_icoanei.pdf

${ }^{22} \mathrm{Pr}$. prof. Ştefan Buchiu, Valoarea teologică a icoanei, p. 7

${ }^{23}$ Paul Evdokimov, Femeia şi mântuirea lumii, Bucureşti, Ed.Christiana, 1995, p.64
} 
the Holy Trinity, in the Son of God. The man created by the "image of God" through the Holy Mysteries, through union with Christ who has reached the likeness of God, is represented by the icons - the Saint. This is the perfect man, the man of the divine plan that is revealed with glory in the Church and who remains present to be the One and Medial Model to God for all Christians. The icons also show that man - as a face of God, is a relational being that cannot live autonomously without God, because logically the image cannot be conceived without participation in his Model, the image being fulfilled by the inclusion in the progressive state of the resemblance to its Archetype, by the grace of the Holy Spirit. But "What is the image or image in the most general sense?" Sergei Bulgakov following St. Gregory of Nyssa says:

\footnotetext{
"The face is a correlative notion with that of its image, that is, its prototype or the original. Therefore, it is first necessary to understand the nature of the face from its relationship with the prototype. Between the chip and the prototype there is both a certain identity and an essential difference, the result of this concomitance is the similarity of" ${ }^{\prime 2}$.
}

Man is a community being fulfilling himself through relationship and collaboration with the divinity and his peers living in grace the fullness of existence ${ }^{25}$. The human consciousness with God through grace in the ecclesial space makes the functions of the image to be realized in the likeness of His Model. This reality expresses the holy icons that reflect the living presence of Christ the God-Man. Thus, the entire life of the Church converges to the divine-humanity of the Person of Christ and to His saving work, committed in the whole humanity assumed as a body ${ }^{26}$. So, the icon embraces mysteriously and paradoxically both the face and the prototype because its foundation is Christ incarnate, sacrificed, resurrected and elevated to heaven in divine glory. That is why the icon is a representation of the transcendent in the immanent, but also of the immanent in the transcendent.

\section{CONCLUSION}

In Orthodox theology, the icon is the reality of God's knowledge and vision. Icon is the expression of the love of God expressed to the utmost through the work of Christ, the Logos, the Creator and the Savior.

The icon in Christian church life and worship has various roles. Firstly, the sacerdotal role because it is holy and sanctifying, thus becoming a reality of the grace of the Holy Spirit. Hence the gods' piety to the cult of the icons. By honoring the holy icons, by living in prayer and in daily life, the Orthodox Christian enters into a relationship with God, which he perceives as a living and working presence through His Saints. Hence, the icon is also an archetype, or rather a model, if we understand it by the reality of the Christological work. Also, the icons have an instructive-educational role, preaching through images the revealed truths of faith, and this didactic activity is fulfilled by the educational-moralizing purpose given by the fulfillment of virtues. Whether in a harp, moralizing, cultic or aesthetic role, the icons meet the need of man to understand the concrete, the material reality that encompasses the spiritual reality through the harsh energies. Thus the icons, through the holy persons represented, show the image of the deified man, therefore theology also speaks of an eschatological character that reveals the Parousia or the second coming of Christ.

\footnotetext{
${ }^{24}$ Serghei Bulgakov, Icoana şi cinstirea Sfintelor icoane, Bucureşti, Ed. Anastasia, 2000 , p.90

${ }^{25}$ Vladimir Soloviov, Fundamentele spirituale ale vieţii, Traducere de Diac. Ioan I. Ică, Editura Deisis, Alba Iulia, 1994, p.88

${ }^{26}$ Cristoph Schonborn, Icoana lui Hristos, ed.cit., 1996, p. 173
} 
In the Orthodox Church the icons, as harsh presence, are considered windows to heaven, and the realities of God's knowledge and vision. In ecclesial, ecclesial icons enhance spiritual perception and guide believers to the kingdom of God, pregnant with the life of communion and love specific to the Church.

\section{BIBLIOGRAPHY:}

[1] Buchiu Pr. prof. Ştefan, Valoarea teologică a icoanei, (Theological value of the icon) V. http://patriarhia.ro/images/pdf/Patrimoniu/Valoarea_teologica_a_icoanei.pdf

[2] Bulgakov Serghei, Icoana şi cinstirea Sfintelor icoane, Bucureşti, Ed. Anastasia, 2000

[3] Bunge Gabriel, Icoana Sfintei Treimi a Cuviosului Andrei Rubliov, traducere de Ioan I.Ică jr., Editura Deisis, Sibiu, 1996,

[4] Evdokimov Paul, Femeia şi mântuirea lumii, Bucureşti, Ed.Christiana, 1995,

[5] Evdokimov Paul, Ortodoxia, trans. Irineu Popa, Bucureşti, 1996,

[6] Lossky Vladimir, Vederea lui Dumnezeu, Editura Deisis, Bucureşti 1995,

[7] Pr. Dumitru Stăniloae, Introducere la Wilhelm Nyssen, Inceputurile picturii bizantine, trans. Pr. D. Stăniloae, Editura IBM al BOR, București

[8] Quenot Michel, Icoana, fereastră spre absolut, Editura Enciclopedică, 1993,

[9] Schonborn Cristoph, Icoana lui Hristos, Bucureşti, Ed. Anastasia, 1996,

[10] Sfântul Dionisie Areopagitul, Despre numele dumnezeieşti, 7, 3, PG 3, 872 a.

[11] Sfântul Ioan Damaschin, Cele trei tratate contra iconoclastilor, trans. D. Fecioru, Bucuresti, 1998 ,

[12] Sfântul Maxim Mărturisitorul, Răspunsuri către Talasie, Filocalia 3, trans. Pr. Prof. Dumitru Stăniloae, Editura Apologeticum, Bucureşti 2005,

[13] Sfântul Teodor Studitul, Antirrheticoss I, P.G., XCIX, col. 330-333

[14] Sfầntul Vasile cel Mare, Despre Sfântul Duh, PSB 12, Editura IBM al BOR, București 1988

[15] Soloviov Vladimir, Fundamentele spirituale ale vieţii, trans. Diac. Ioan I. Ică, Editura Deisis, Alba Iulia, 1994,

[16] Stăniloae Pr. Dumitru, Chipul nemuritor al lui Dumnezeu, vol. I; Editura. Cristal, Bucureşti 1995 ,

[17] Stăniloae Pr. Prof. Dumitru, Teologia Dogmatică Ortodoxă, vol I, Editura IBM al BOR, IInd edition, Bucureşti, 1996

[18] Stăniloae Prof. Pr. Dumitru, Semnificația luminii dumnezeieşti în spiritualitatea şi cultul Bisericii Ortodoxe, in Ortodoxia, no. 3-4/ 1976,

[19]Turcescu Lucian, Sfântul Grigore Palama teologia trinitară, în „Studii Teologice”, no. 4$6 / 1995$,

[20] Uspensky Leonid, Teologia icoanei, trans. Teodor Baconsky, Ed. Anastasia, Bucureşti, 1994, 